\title{
Research on the influencing factors of college students online shopping under B2C model
}

\author{
Jimin Guo \\ International Business School \\ Yunnan University of Finance and Economics \\ Kunming, China \\ 2362573049@qq.com
}

\author{
Yunlong Duan* \\ International Business School \\ Yunnan University of Finance and Economics \\ Kunming, China \\ 827987867@qq.com
}

\begin{abstract}
With the popularity of the domestic Internet and the vigorous development of e-commerce industry, online shopping has set off an upsurge. Online shopping is active in the domestic economic market with its unique advantages. In the proportion of Internet users in China, college students account for a large proportion. They are a new generation of consumer groups growing up with the Internet. Compared with other consumer groups, college students have stronger network operation skills and have high dependence on the network. College students are the main force of online consumption, so it is important to seize the groups. This paper takes college students as the object, and based on a large number of literature on influencing factors, summarizes the research results and sets up variables. The study found that the quality of service, safety factor, system quality has a significant positive impact on customer satisfaction, service quality, system quality, information quality has a significant positive impact on trust, information quality, system quality has a significant positive impact on the safety factor.
\end{abstract}

Keywords-B2C e-commerce platform; college students; online shopping; influencing factors

\section{INTRODUCTION}

With the rapid development of e-commerce, China's online shopping matures, and its convenience to people's lives has been recognized by more and more consumers, China's online shopping market scale is also expanding. At the same time, competition in the market is also increasing. Therefore, the satisfaction of consumers is particularly important for the development of online shopping. With the development of electronic commerce becoming more and more mature, $\mathrm{B} 2 \mathrm{C}$ (Business to Customer) of the enterprise through the network directly to sold the goods or services to the consumer ecommerce model with its amazing momentum to occupy a major share of e-commerce market [1]. Good user experience is a key factor to B2C's continue survival, but Zhang Mei pointed out some problems that existing in B2C website,such as slow logistics, online payment problems, the quality of customer service, resulting in the satisfaction of users in online transaction process is relatively low [2]. Patterson (1997) [3]study found in the turbulence electronic commerce environment, customer's satisfaction is the key to establish long-term customer relationship, so the online business enterprises need to know how to improve customer's satisfaction, in order to maintain sustained growth and expand the market share [4].

\section{LITERATURE REVIEW}

Paul A.Pavlou (2003) [7] proposed that site reliability, easy perceive of online shopping process have a good effect to consumer's shopping attention; risk perceive factors in the process of online shopping has the negative effect on online shopping intention. The degree higher, the lower the online shopping intention is [5]. Gefen and Straub's (2001) [20] study shows that for potential consumers, usability is mainly reflected in the search engine, intuitive clarity, so company's attention should be paid to the Web site search's engine [6]. Sutton \& Hallett (1989) [7] believes that past experience can predict future behavior, satisfaction degree of network consumers on the service quality of online stores will affect whether consumers return to this website. Hassan Esmailpour (2012) [21] through the study of Iran consumers, obtained 4 kinds of impact on the consumption behavior of network user factors, and these factors were compared respectively and ranked,service quality, the price of the product itself and website design, personal information security. Yen-Ting (2012) et al [8] believed that consumer's satisfaction is a decisive factor that ultimately affects their consumption behavior, businesses should pay attention to commodity sale and customer service.

Lin Zhixin (2013) [9] in the study of information behavior of network consumption behavior of college students decision showed that College Students' information search behavior, information browsing behavior, shopping information interaction behavior had a significant positive effect of consumer perceived value; the perception of risk had negative impact on college students' shopping behavior, shopping risk perception had negative impact on perception of value. Xiao Fengzhen (2011) [10] in the study of factors affecting college students' network consumption behavior showed that College students' network consumption behavior intention has direct influence on online consumer behavior .Besides web site features are different, so that they formed in the process of network consumer behavior of different network consumer behavior habits. Liu Ling (2015) [11] found that college students' online consumer sentiment, attitude, satisfaction and trust were positively affected by commodity factors and service factors when they studied the influencing factors of online

\footnotetext{
* Corresponding author
} 
consumer behavior of college students. Liu Kan, Xie Jing, Zhuang Yulong by the empirical method factor analysis found six factors influencing college students' choice of online shopping: business service factor, logistics service factor, site factor, credit guarantee factor and shopping cost factor. Among them, the business service factor had the greatest impact on the online shopping choice behavior of college students [12]. Chen Liying (2011) [13] studied the influencing factors of consumers' purchase intention on consumer websites, and believed that consumer trust mainly reflects the trust of websites and the service trust offered by websites.

\section{HYPOTHESIS PROPOSITION}

Consumers want to buy their own cost-effective goods, especially for college students, they do not have enough money, but also love the pursuit of fashion, the pursuit of brand so online shopping has become a good choice. Online shopping platform has many brands and discount activities, there are some special sale sites such as vip.com, jumei.com. Product quality also is an important factor, only to improve the consumer's online shopping satisfaction can encourage consumers' second-time purchase. Based on the above analysis, the following hypotheses are proposed:

H1: Commodity factor has a positive impact on College Students' satisfaction.

H2: Commodity factor has a positive impact on College Students' trust

Li Binbin, Wang Hongyan and Zhang Nan believed that network security affects students whether choose online shopping [14]. Schmidt JB, Spring.AR and other scholars believed that although online shopping for consumers provides a new and convenient way to buy, but also with more new shopping risk compared with the traditional in store shopping, consumers in online shopping because of the lack of a sense of security and privacy risks [15]. Cao Liqun, Liu Huilan (2012) [16] through the analysis of the development of the network in China, carried out research on consumer online shopping motivation showed factors that influence consumer online shopping including online payment security, the quality of sales and service network and consumer convenience. $\mathrm{Li}$ Tingchun (2009) [17] pointed out that network security directly restricts network consumption, and proposed to ensure the safety of network consumption from the aspects of guaranteeing the personal identity of users, security, fund security and cargo safety. Therefore, the protection of customer's payment security, information security, commodity safety is the first should to consider. Based on the above analysis, the following hypotheses are proposed:

H3: Safety factors has a positive impact on College Students' satisfaction.

H4: Security factors has a positive impact on College Students' trust.

The main way consumers identify goods and services is the integration of various information and then a preliminary understanding of the goods. Whether the website's product and service information is clear, whether it is easy to understand, whether it is true, effective and complete will affect the shopper's understanding of the product. If the consumers get amount of insufficient information or inaccurate information, unable to form a complete and clear understanding of the goods, it is easy to give up shopping. Based on the above analysis, the following hypotheses are proposed:

H5: Information quality has a positive impact on College Students' satisfaction

H6: Information quality has a positive impact on the confidence of College Students

Novak believed that website security technology affects consumers' consumption, simply said, " the open speed of website channel is stable, and the website design will have an impact on consumers' online shopping. Domestic scholars Chen Linfen and Wang Zhongming believed that customer perception of network quality will directly affect whether or not they make decisions about network consumption. Through the study of online shopping loyalty of college students, Wang Zhaogang believed that network design and frequently updated catalogues will help promote online consumption among college students. The fluency of the shopping website and the style of the website will influence the shopping experience of the user. Based on the above analysis, the following hypotheses are proposed:

H7:The system quality of the website has a positive impact on satisfaction

H8: The system quality of a website has a positive impact on trust

There are a variety of online payment,but everyone's choice is different if the site's payment ways is few will affect the consumer's shopping choice,so consumers would choose other shopping sites which has more payment ways. The website's operation procedure is tedious, the website cannot provide the good search function will affect the consumer's shopping experience. Paul (2005) [18] studied that organizational structure of navigation system and practical clear and simple transaction process is the necessary factor of attracting consumers, these factors are important to absorb people that never have shopping online experience before. Myung etc (2011) [19] for South Korea's tourism electronic product data for research on the navigation function and consumer website satisfaction, and ultimately had important influence on the choice of network consumption conclusion. Many studies had shown a strong correlation between web site usability and consumer satisfaction with the site [20]. Based on the above analysis, the following hypotheses are proposed:

H9: Website usability has a positive impact on College Students' satisfaction.

H10: Website usability has a positive impact on College Students' trust.

Parasuraman and others belied that higher the quality of service, higher the customer satisfaction. Kim (2012) etc [21] studied that the quality of service, network system design, information directly affects the quality of network shopping value, and will affect the network user consumption. Guo $\mathrm{Yu}$ (2012) [22] by research on the C2C website showed that consumers satisfied price, more concerned about service 
quality and other risks, while the $\mathrm{B} 2 \mathrm{C}$ is not satisfied with the price, but the quality of service, feel good. In this way, the author concludes that the factors that affect consumer behavior are service quality, network risk and price factor. Based on the above theories, the following hypotheses are proposed:

H11: Service factors have a positive impact on College Students' satisfaction.

H12: Service factors have a positive impact on College Students' trust.

Okky, Kartavianus (2012) etc [23] believed that trust factors have the greatest impact on consumer choice of network consumption. Hcc-woong, Kim (2012) etc [21] analyze the influencing factors of consumer choice of network consumption behavior on the two dimensions of price and trust. The results show that, compared to the price, the degree of trust of consumers make decisions more consumers on the website of the trust is high, the more will be repetitive and is willing to buy a large amount of transaction. Gefen (2000) [25] found that higher the degree of trust in the Amazon.com study, higher the proportion of actual consumption. Emotional attitude variables, satisfaction and trust degree of college students have significant positive impact on online shopping behavior of College students. Based on the above analysis, the following hypotheses are proposed:

H13:College Students' satisfaction has a positive impact on students' shopping intention

H14:College Students' trust has a positive impact on students' shopping intention

\section{DATA ANALYSIS}

\section{A. Sample selection and data collection}

This paper mainly takes college students as the research object, and adopts the questionnaire survey method. Questionnaire items mainly by Li Kerte (Likert) five scale design. All total of 300 documents were issued, and 267 questionnaires were collected. 65 invalid questionnaires with regular answers or incomplete answers were eliminated, and 202 valid questionnaires were received. This independent variable extracts six types of perceptual variables through the literature review and the hypotheses section. Commodity factors; platform service quality; website system quality; website usability. Dependent variable selection satisfaction.

\section{B. Data Processing and Analysis}

\section{1) Test of Reliability and Validity}

In order to test the reliability of the survey data and conclusions, the reliability of the questionnaire was tested. The Cronbach 's alpha (alpha) coefficient is the most commonly used method of reliability test. Usually, when the alpha coefficient is greater than 0.7 the questionnaire measurement results are valid. In this paper, the safety factor of perception variable service factors, website usability, system quality, four variables and perception satisfaction, and shopping intention, including reliability analysis project, where the variable Cronbach's values are greater than 0.7 , indicating that this research questionnaire measurement has the well consistency and stability , this study also shows that the questionnaire has good reliability, preliminary determination of this research can be the next step.

TABLE I. RELIABILITY ANALYSIS

\begin{tabular}{|l|l|l|l|l|}
\hline \multicolumn{1}{|c|}{ variable } & $\begin{array}{c}\text { Num } \\
\text { ber }\end{array}$ & $\begin{array}{c}\text { Cronbach } \\
\text { s alpha }\end{array}$ & \multicolumn{2}{|c|}{$\begin{array}{c}\text { Cronbach 's alpha coefficients } \\
\text { based on normalization terms }\end{array}$} \\
\hline $\begin{array}{l}\text { Commodity } \\
\text { factor }\end{array}$ & 4 & 0.714 & 0.716 & $\begin{array}{l}\text { reliability } \\
\text { coefficients } \\
\text { are above } \\
0.7\end{array}$ \\
\hline Safety factor & 4 & 0.794 & 0.794 & \\
\hline Service factor & 6 & 0.828 & 0.834 & \\
\hline $\begin{array}{l}\text { Information } \\
\text { quality }\end{array}$ & 4 & 0.875 & 0.876 & \\
\hline System quality & 3 & 0.826 & 0.826 \\
\hline Usability & 3 & 0.887 & 0.888 \\
\hline $\begin{array}{l}\text { Satisfaction } \\
\text { degree }\end{array}$ & 3 & 0.894 & 0.895 \\
\hline Trust degree & 3 & 0.891 & 0.892 \\
\hline $\begin{array}{l}\text { Shopping } \\
\text { intention }\end{array}$ & 3 & 0.880 & 0.879 \\
\end{tabular}

The correct measurement of the effective degree of validity or measurement, whether reasonable and effective measure to research the variables determined by data. In this study, validity analysis is selected, and factor analysis is used in structural validity analysis. In this paper, the KMO sample index and Bartley Bartlett sphericity test index are used to validate and measure the validity of the questionnaire.

TABLE II. VALIDITY TEST

\begin{tabular}{|l|l|l|}
\hline \multicolumn{2}{|c|}{ Kaiser-Meyer-Olkin metrics for sampling sufficiency } & \multicolumn{1}{c|}{$\mathbf{0 . 9 1 9}$} \\
\hline \multirow{4}{*}{ test of Bartlett Spherical } & Approximate chi square & 4410.641 \\
\cline { 2 - 3 } & df & 528 \\
\cline { 2 - 3 } & Sig. & 0.000 \\
\hline
\end{tabular}

As can be seen from the above table, the KMO of the sampling sufficiency is 0.919 , and the significance probability of the Bartlett sphericity test is 0 . It can be concluded that the construct validity is better, and the sample data is significantly related.

\section{2) Correlation Analysis}

In this paper, the Pearson simple correlation coefficient is used to analyze and measure the correlation between the variables and dependent variables. The specific conditions are shown in table :

TABLE III. CORRELATION ANALYSIS

\begin{tabular}{|c|c|c|c|c|c|c|c|c|c|}
\hline $\begin{array}{c}\text { Pearso } \\
n\end{array}$ & $\begin{array}{l}\text { Com } \\
\text { modi } \\
\text { ty } \\
\text { facto } \\
r\end{array}$ & $\begin{array}{l}\text { Saf } \\
\text { ety } \\
\text { fact } \\
\text { or }\end{array}$ & $\begin{array}{l}\text { Servi } \\
\text { ce } \\
\text { factor }\end{array}$ & $\begin{array}{l}\text { Inf } \\
\text { orm } \\
\text { atio } \\
n\end{array}$ & $\begin{array}{l}\text { Sy } \\
\text { ste } \\
m\end{array}$ & $\begin{array}{c}\text { usa } \\
\text { bili } \\
\text { ty }\end{array}$ & $\begin{array}{c}\text { Satis } \\
\text { facti } \\
\text { on } \\
\text { degr } \\
\text { ee }\end{array}$ & $\begin{array}{c}\text { Tr } \\
\text { ust } \\
\text { deg } \\
\text { ree }\end{array}$ & $\begin{array}{c}\text { Sho } \\
\text { ppin } \\
g \\
\text { desir } \\
e \\
\end{array}$ \\
\hline $\begin{array}{l}\text { Comm } \\
\text { odity } \\
\text { factor }\end{array}$ & 1 & $\begin{array}{l}0.4 \\
83\end{array}$ & 0.518 & $\begin{array}{l}0.4 \\
70\end{array}$ & $\begin{array}{l}0.5 \\
04\end{array}$ & $\begin{array}{l}0.3 \\
89\end{array}$ & $\begin{array}{l}0.57 \\
7 * *\end{array}$ & $\begin{array}{l}0.5 \\
48^{*} \\
*\end{array}$ & $\begin{array}{l}0.57 \\
7\end{array}$ \\
\hline $\begin{array}{l}\text { Safety } \\
\text { factor }\end{array}$ & $\begin{array}{l}0.48 \\
3\end{array}$ & 1 & 0.527 & $\begin{array}{l}0.4 \\
33\end{array}$ & $\begin{array}{l}0.4 \\
72\end{array}$ & $\begin{array}{l}0.5 \\
06\end{array}$ & $\begin{array}{l}0.47 \\
3 * *\end{array}$ & $\begin{array}{l}0.5 \\
18^{*} \\
*\end{array}$ & $\begin{array}{l}0.41 \\
4\end{array}$ \\
\hline $\begin{array}{l}\text { Servic } \\
\mathrm{e} \\
\text { factor }\end{array}$ & $\begin{array}{l}0.51 \\
8\end{array}$ & $\begin{array}{l}0.5 \\
27\end{array}$ & 1 & $\begin{array}{l}0.5 \\
82\end{array}$ & $\begin{array}{l}0.5 \\
53\end{array}$ & $\begin{array}{l}0.4 \\
72\end{array}$ & $\begin{array}{l}0.56 \\
9 * *\end{array}$ & $\begin{array}{l}0.6 \\
10 * \\
*\end{array}$ & $\begin{array}{l}0.49 \\
6 * *\end{array}$ \\
\hline Inform & 0.47 & 0.4 & 0.582 & 1 & 0.5 & 0.4 & 0.52 & 0.4 & 0.42 \\
\hline
\end{tabular}




\begin{tabular}{|c|c|c|c|c|c|c|c|c|c|}
\hline ation & 0 & 33 & & & 46 & 28 & $5 * *$ & $\begin{array}{l}95^{*} \\
*\end{array}$ & $0 * *$ \\
\hline $\begin{array}{l}\text { Syste } \\
\mathrm{m}\end{array}$ & $\begin{array}{l}0.50 \\
4\end{array}$ & $\begin{array}{l}0.4 \\
72\end{array}$ & 0.553 & $\begin{array}{l}0.5 \\
46\end{array}$ & 1 & $\begin{array}{l}0.4 \\
56\end{array}$ & $\begin{array}{l}0.54 \\
4 * *\end{array}$ & $\begin{array}{l}0.5 \\
33^{*} \\
*\end{array}$ & $\begin{array}{l}0.49 \\
4 * *\end{array}$ \\
\hline usality & $\begin{array}{l}0.38 \\
9\end{array}$ & $\begin{array}{l}0.5 \\
06\end{array}$ & 0.472 & $\begin{array}{l}0.4 \\
28\end{array}$ & $\begin{array}{l}0.4 \\
56\end{array}$ & 1 & $\begin{array}{l}0.45 \\
1 * *\end{array}$ & $\begin{array}{l}0.4 \\
63^{*} \\
*\end{array}$ & $\begin{array}{l}0.39 \\
4 * *\end{array}$ \\
\hline $\begin{array}{l}\text { Satisfa } \\
\text { ction } \\
\text { degree }\end{array}$ & $\begin{array}{l}0.57 \\
7 * *\end{array}$ & $\begin{array}{l}0.4 \\
73 * \\
*\end{array}$ & $\begin{array}{l}0.569 \\
* *\end{array}$ & $\begin{array}{l}0.5 \\
25^{*} \\
*\end{array}$ & $\begin{array}{l}0.5 \\
44 \\
* *\end{array}$ & $\begin{array}{l}0.4 \\
51 \\
* *\end{array}$ & 1 & $\begin{array}{l}0.7 \\
73 * \\
*\end{array}$ & $\begin{array}{l}0.73 \\
1 * *\end{array}$ \\
\hline $\begin{array}{l}\text { Trust } \\
\text { degree }\end{array}$ & $\begin{array}{l}0.54 \\
8 * *\end{array}$ & $\begin{array}{l}0.5 \\
18^{*} \\
*\end{array}$ & $\begin{array}{l}0.610 \\
* *\end{array}$ & $\begin{array}{l}0.4 \\
95^{*} \\
*\end{array}$ & $\begin{array}{l}0.5 \\
33 \\
* *\end{array}$ & $\begin{array}{l}0.4 \\
63 \\
* *\end{array}$ & $\begin{array}{l}0.77 \\
3 * *\end{array}$ & 1 & $\begin{array}{l}0.71 \\
6 * *\end{array}$ \\
\hline $\begin{array}{l}\text { Shoppi } \\
\text { ng } \\
\text { desire }\end{array}$ & $\begin{array}{l}0.57 \\
7\end{array}$ & $\begin{array}{l}0.4 \\
14\end{array}$ & $\begin{array}{l}0.496 \\
* *\end{array}$ & $\begin{array}{l}0.4 \\
20 * \\
*\end{array}$ & $\begin{array}{l}0.4 \\
94 \\
* *\end{array}$ & $\begin{array}{l}0.3 \\
94 \\
* *\end{array}$ & $\begin{array}{l}0.73 \\
1 * *\end{array}$ & $\begin{array}{l}0.7 \\
16^{*} \\
*\end{array}$ & 1 \\
\hline
\end{tabular}

a. **.Significant correlation was found at the 0.01 level (bilateral)

From the table we can see that commodity factors, safety factors, quality of service, website usability, information quality and students' satisfaction and trust have significant positive correlation, a significant positive correlation between students' satisfaction and trust, satisfaction degree of college students shopping intention significant positive correlation.

\section{Regression Analysis}

1) First, the goodness of fit of the model is tested, and the regression equation is well fitted. Satisfaction was the dependent variable: the regression analysis was made with the satisfaction factor as the dependent variable, the security factor, the commodity factor, the service quality, the website system quality, the information quality and the website usability as independent variable

TABLE IV. REGRESSION ANALYSIS

\begin{tabular}{|c|c|c|c|c|c|}
\hline \multicolumn{6}{|c|}{$\alpha$} \\
\hline Model & \multicolumn{2}{|c|}{$\begin{array}{l}\text { unstandardized } \\
\text { coefficients }\end{array}$} & \multirow{2}{*}{$\begin{array}{l}\begin{array}{l}\text { Standard } \\
\text { coefficie } \\
\text { nts }\end{array} \\
\text { Bete }\end{array}$} & \multirow[t]{2}{*}{$t$} & \multirow[t]{2}{*}{ Sig. } \\
\hline & $B$ & $\begin{array}{c}\text { Std.erro } \\
r\end{array}$ & & & \\
\hline constant & 0.339 & 0.243 & & 1.391 & 0.166 \\
\hline $\begin{array}{l}\text { Commodity } \\
\text { factor }\end{array}$ & 0.292 & 0.070 & 0.271 & 4.163 & 0.000 \\
\hline Security factor & 0.061 & 0.064 & 0.063 & 0.948 & 0.344 \\
\hline $\begin{array}{l}\text { Information } \\
\text { factor }\end{array}$ & 0.132 & 0.066 & 0.136 & 2.008 & 0.046 \\
\hline System factor & 0.164 & 0.071 & 0.157 & 2.297 & 0.023 \\
\hline Usibility factor & 0.089 & 0.059 & 0.097 & 1.527 & 0.128 \\
\hline Service factor & 0.197 & 0.078 & 0.183 & 2.536 & 0.012 \\
\hline
\end{tabular}

Table regression analysis showed that the absolute value of commodity factors, information quality, system quality, service factor $\mathrm{T}$ values were greater than $2, \mathrm{P}$ value was less than 0.05 , only the absolute value of safety factor, the usability of $\mathrm{T}$ value is less than 2 , and the $P$ value is greater than 0.05 . So the security factor and ease of use are eliminated from the model. Therefore, the commodity factors, information quality, system quality and service quality have a significant positive impact on College Students' satisfaction.

Therefore, the regression equation can be established :

\section{$\mathrm{Y} 1=0.292 \mathrm{X} 1+0.132 \mathrm{X} 3+0.164 \mathrm{X} 4+0.197 \mathrm{X} 6$}

1) Trust as the dependent variables: the dependent variable to trust,to safety factor, product factor, service quality, system quality, information quality,website usability as independent variables in regression analysis, the specific steps are as follows:

TABLE V. REGRESSION ANALYSIS

\begin{tabular}{|c|c|c|c|c|c|}
\hline \multicolumn{6}{|c|}{$\alpha$} \\
\hline \multirow[t]{2}{*}{ Model } & \multicolumn{2}{|c|}{$\begin{array}{l}\text { Unstandardized } \\
\text { coefficients }\end{array}$} & \multirow{2}{*}{$\begin{array}{l}\text { Standard } \\
\text { coefficien } \\
\text { ts }\end{array}$} & \multirow[t]{2}{*}{$t$} & \multirow[t]{2}{*}{ Sig. } \\
\hline & $B$ & $\begin{array}{l}\text { Std.err } \\
\text { or }\end{array}$ & & & \\
\hline Constant & 0.208 & 0.246 & & 0.844 & 0.400 \\
\hline Commodity factor & 0.223 & 0.071 & 0.204 & 3.148 & 0.002 \\
\hline Security factor & 0.131 & 0.065 & 0.133 & 2.020 & 0.045 \\
\hline Information factor & 0.065 & 0.067 & 0.066 & 0.977 & 0.330 \\
\hline System factor & 0.143 & 0.072 & 0.135 & 1.986 & 0.048 \\
\hline Usability factor & 0.090 & 0.059 & 0.095 & 1.516 & 0.131 \\
\hline Service factor & 0.303 & 0.078 & 0.276 & 3.865 & 0.000 \\
\hline \multicolumn{6}{|c|}{ Dependent variable: trust degree } \\
\hline
\end{tabular}

Table regression analysis showed that the absolute value of commodity factors, information quality, system quality, safety factor, service factor $\mathrm{T}$ values were greater than $2, \mathrm{P}$ value was less than 0.05 , only the information quality, ease of use of the $T$ value of the absolute value is less than 2 , and the $P$ value is greater than 0.05 . Therefore, the quality of information and ease of use are eliminated from the model. Therefore, the commodity factors, information quality, system quality and service quality have a significant positive impact on the confidence of College students.

Therefore, the regression equation can be established :

$$
\mathrm{Y} 2=0.223 \mathrm{X} 1+0.131 \mathrm{X} 2+0.143 \mathrm{X} 4+0.303 \mathrm{X} 6
$$

2) Online shopping intention as dependent variable: regression analysis was conducted with satisfaction and trust as independent variables :

TABLE VI. REGRESSION ANALYSIS

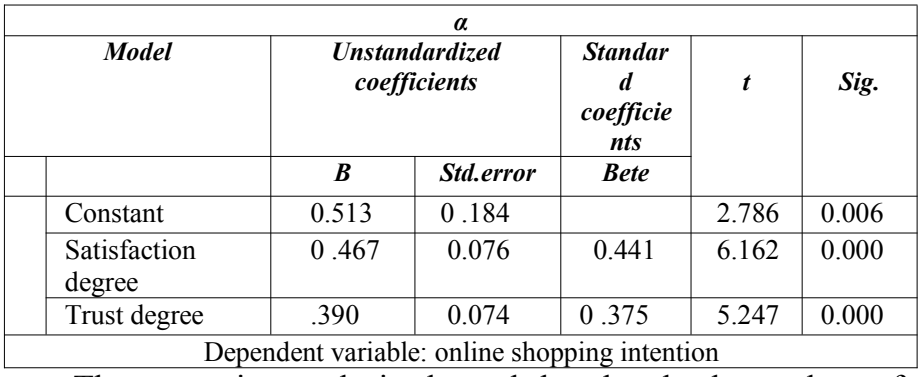

The regression analysis showed that the absolute values of $T$ values of satisfaction and trust were greater than 2 , and the $P$ values were less than 0.05 . Therefore, satisfaction and trust have a significant positive impact on College Students' shopping intention.

Therefore, the regression equation can be established: 


\section{$\mathrm{Z}=0.467 \mathrm{Y} 1+0.390 \mathrm{Y} 2+0.513$}

3) In the analysis of multicollinearity when we find that the system quality, ease of use, the safety factor between the endogenous relationship, so the safety factor as the dependent variable: system quality, website usability as independent variables, regression analysis was carried out as follows:

TABLE VII. REGRESSION ANALYSIS

\begin{tabular}{|c|c|c|c|c|c|}
\hline \multicolumn{6}{|c|}{$\alpha$} \\
\hline \multirow[t]{2}{*}{ Model } & \multicolumn{2}{|c|}{$\begin{array}{c}\text { Unstandardized } \\
\text { coefficients }\end{array}$} & \multirow{2}{*}{$\begin{array}{c}\begin{array}{c}\text { Standard } \\
\text { coefficien } \\
\text { ts }\end{array} \\
\text { Bete }\end{array}$} & \multirow[t]{2}{*}{$t$} & \multirow[t]{2}{*}{ Sig. } \\
\hline & $\boldsymbol{B}$ & Std.error & & & \\
\hline Constant & 1.068 & 0.256 & & 4.178 & 0.000 \\
\hline Usability & 0.352 & 0.062 & 0.367 & 5.630 & 0.000 \\
\hline System quality & 0.328 & 0.070 & 0304 & 4.663 & 0.000 \\
\hline \multicolumn{6}{|c|}{ Dependent variable: safety factor } \\
\hline
\end{tabular}

The results of regression analysis showed that the absolute values of the $T$ value of the system and the usability were greater than 2 , and the $P$ values were less than 0.01 . As a result, ease of use and system quality have a significant positive impact on safety factors.

Therefore, the regression equation can be established:

\section{$\mathrm{Z}=0.352 \mathrm{Y} 1+0.328 \mathrm{Y} 2+1.068$}

Through the above data analysis results, we can see that the commodity factors, information quality, system quality, service quality has a positive impact on satisfaction; commodity factors, safety factors, system quality, service quality has a positive impact on trust; satisfaction and trust of online shopping will have a positive impact; so $\mathrm{H} 1, \mathrm{H} 2, \mathrm{H} 4, \mathrm{H} 5, \mathrm{H} 7$ $\mathrm{H} 8, \mathrm{H} 11, \mathrm{H} 12, \mathrm{H} 13, \mathrm{H} 14$, has been verified, and the service quality of college students online shopping trust has a positive effect on College Students' quality of service, trust degree has a positive impact on online shopping

\section{MAIN ReSEARCh CONCLUSIONS AND IMPLiCATIONS}

The emotional attitude and trust degree of college students in B2C online shopping mall are positively affected by security factors, which shows that college students have a high demand for network security. In particular, they are concerned about the protection of their private information and the safety of their funds. The higher the security of the website, the higher the degree of emotion recognition the they have. Based on the above analysis, we should optimize and upgrade the safety protection system of their own $\mathrm{B} 2 \mathrm{C}$ site, guarantee the safety of consumers pay and account security; B2C shopping platform logistics such as the Jingdong to establish and perfect the rules and regulations of logistics system of their own.

College Students' attitude "satisfaction" and "trust" has significant positive influence factors of commodity. The convenience of online shopping is the main factor to attract college students to shop online but the quality and price of commodities is the focus of their attention. Therefore, the B2C website should constantly improve their own purchase channels, reduce the price of the product to ensure product quality; there is also a need to expand the business scope, provide more products for consumers, but also to meet the personalized needs of consumers .

College Students' online shopping attitudes "satisfaction" and "trust" has significant positive influence factors of service, whether college students pay attention to the website can fulfill its commitments, guarantee the customer service timely processing of the problem of return; whether to enthusiasm, timely help consumers solve the shopping process concerns.Therefore, the $\mathrm{B} 2 \mathrm{C}$ website should enhance service level, for the return of consumer demand should timely treatment; timely to distribution customer orders and timely processing the orders; a disadvantage of $\mathrm{B} 2 \mathrm{C}$ website is the customer service, customers can not get the server's reply timely . It is recommended that $\mathrm{B} 2 \mathrm{C}$ website should strengthen customer service, if conditions permit to provide adequate customer service for consumers.

College Students' online shopping attitudes "satisfaction" and "trust" by the website information quality has a significant positive influence, which shows accurate degree, students provided on the $\mathrm{B} 2 \mathrm{C}$ website of commodity information integrity, is it easy to understand more attention. Incomplete, inaccurate and difficult to understand information will make their shopping puzzled. Only when the information is accurate, complete and easy to understand can it fully show the characteristics of the goods, and consumers will have a full understanding of the product information to improve their purchasing intention. Therefore, the $\mathrm{B} 2 \mathrm{C}$ website should improve the quality of web page for details of the goods, to provide complete and accurate, easy-understanding product information.

College Students' online shopping attitudes "satisfaction" and "trust" by the website system quality has a significant positive effect that the technical conditions, the site itself page design, page response speed of classification, commodity sector will have an impact on their emotional attitude, the more mature technology of website, browse the web design more smoothly; new, more natural and comfortable shopping environment, consumer sentiment is better. The B2C website to optimize their system, timely site technical innovation, reduce the page response time, increase the fluency of the website; pages to enhance the design level, to ensure the site's appearance and practicality of the optimization; the classification of goods for consumers to buy.

\section{ACKNOWLEDGMENT}

Thanks to the International Business School of Yunnan University of Finance and Economics that create a good academic environment and contribute opportunities for us. First of all, I'd like to express my special thanks to my dear teacher Yunlong Duan. Thanks to my teacher in his busy time can have time to teach my paper. The teacher's advice on the completion of this paper plays a very important guiding role.Due to the lack of personal ability, this paper has many shortcomings, I hope the teacher can give criticism and correction. 


\section{REFERENCES}

[1] J. Zhang, and Y. Zhao, "Research on user experience evaluation of Yu Hong. B2C e-commerce website," Information Science. vol. 31, Twelfth issue, December 2013.

[2] M. Zhang, "Some questions on the development of B2C in China," Journal of Beijing Institute of planned labor management, 2002, pp. 41 45.

[3] Patterson, G. Paul, W. Lester, and A. Spring, "Modeling the Determinants of Customer Satisfaction for Business to business Professional Services," Academy of Marketing Science Journal, 1997, p. 417.

[4] M. Kinney, Vicki, K.Y. Yoon, and Zahed, "The Measurement of WebCustomer Satisfaction:An Expectation and Disconfirmation Approach," Information System Research, 2002, pp. 296 -315.

[5] A. Paul, "Consumer Acceptance of Electronic Commerce:Integrating Trust and Risk with the Technology Acceptance Model,'International Journal of Electronic Commerce, 2002, pp. 101-134.

[6] D. Gefen, and D.W. Straub, "The Relative Importance of Perceived Ease-of-use in IS Adoption:A Study of E-Commerce Adoption," Journal of the Association for Information Systems, 2001.

[7] S.R. Sutton, and R. Hallett, "Understanding seat-belt intentions and behavior:a decision-making approach,"Journal of applied Social Psychology, 2003, pp. 1310-1325.

[8] Y.T. Chen, and T.Y. Chou, "Exploring the continuance intentions of consumers for B2C online shopping:Perspectives of fairness and trust," Emerald 36,vol. 34, 2012, pp. 1102-1114.

[9] Lin, "Study on information behavior of College Students' Internet decision making," Chengdu press, 2013.

[10] F.Z. Xiao, "Empirical Study on the influence factors of College Students' online shopping," Science and Technology Management Research, 2011, pp. 131-134.

[11] L. Liu, "Research on Influencing Factors of College Students' online consumer behavior," Huai nan:An hui Science And Engineering, pp. 19, 2015 .
[12] K. Liu, J. Xie, and E. Zhuang, "Empirical Study on the factors influencing college students' online shopping decision," Electric Commerce, 2010, pp. 86-87.

[13] P. Kotler, "Marketing Management Analysis,Planning Implementation and Control," Prentice-Hall, 1997, pp. 132-133.

[14] B.B. Li, H.Y. Wang, and N. Zhang, "Study on College Students' online shopping loyalty cultivation," Consumer Research, 2010, pp. 16-1 7.

[15] J.B. Schmidt, and A.R. Spring, "A proposed model of external consumer informati on search,"Journal Of Bank Marketing Science,Vol 24, 1996, pp. 246-256.

[16] L.Q. Cao, and H.L. Liu, "Talking about factors affecting consumer online shopping," Quotient, 2012, p. 54.

[17] T.C. Li, "Network sharing Security problems and Countermeasures," Consumer Economy, 2009, pp. 80-83.

[18] S.S Paul, "Factors that affect attitude toward a retail web site," Journal of Marketing Theory and Practice, 2005, p. 41.

[19] J. Myung. "The effect of perceived trust on electronic commerce, shopping online for tourism products and services in south Korea," Tourism Management, 2012, pp. 256-265.

[20] Z. Yang, R.T. Peterson, and L. Huang, "Taking the pulse of Internet Marketing," Health Services, 2001, pp. 4-10.

[21] K.S. Bradley, "Toward an evolution strategy for the digital goods business,"Ma Management Decision, 2012, pp. 234-252.

[22] Y.Guo, "Study on the influencing factors of consumer online shopping," Shanghai:Shanghai Jiao Tong University, 2012, pp. 19-20.

[23] T.A. Kartavianus, "Determining Factors on Purchasing Decision Through E-Commerce: A Structural Equations Modeling Framework," Procedure Engineering, 2012, pp. 463-473.

[24] W.K. Hee, and Y. Xu, "Which is more important in internet shopping: perceived price or trust," Electronic Commerce Research Applications,vol. 11, 2012, pp. 241-252.

[25] D. Gefen, "E-commerce:the role of familiarity and trust. Omega," The International Journal of Management Science, vol. 28, 2000, pp. 725737. 